\title{
12. CENOZOIC OSTRACODES: THEIR IMPORTANCE FOR BATHYMETRY, HYDROLOGY, AND BIOGEOGRAPHY
}

O. Ducasse and J.P. Peypouquet, Centre de Recherches sur l'Environment, sedimentaire et structural des domaines marins, Université de Bordeaux 1, 351 Cours de la Liberation, Talence, France

\section{INTRODUCTION}

Cenozoic ostracodes from Leg 48 of the IPOD program have been studied for the purpose of paleoecology. The aim is to define the environment as precisely and completely as possible and to arrive at an understanding of the evolution of the faunal associations throughout the course of time, in terms of nature and number, as reflected and explained by the hydrologic conditions: depth, $\mathrm{T}^{\circ} \mathrm{C}$, dissolved $\mathrm{O}_{2}$, nutritional supply, intensity of bottom circulation, etc.

Two areas were studied - the northern continental margin of the Bay of Biscay and the southwestern extremity of the Rockall Plateau.

About one hundred samples from six sites (400/400A, $402 / 402 \mathrm{~A}, 403,404,405,406)$ in the northeastern Atlantic were analyzed. They represent a period extending from the Paleocene to the Quaternary.

\section{FAUNA FROM THE VARIOUS SITES}

The ostracode microfauna is well preserved but generally poor and largely undiversified; it is characteristic of deepwater environments.

\section{Northern Continental Margin of the Bay of Biscay}

\section{Hole 400A (Figure 1)}

The fauna is poor with little variety. From the base of the Tertiary to the top of the lower Miocene, only juvenile forms of Krithe and Agrenocythere, an internal molds of Buntonia and a few unidentifiable fragments were recovered. The upper part of the sequence is marked by a development of Henryhowella asperrima (Reuss) (PI. 3, Fig. 1), associated with less abundant Krithe, Parakrithe, and Poseidonamicus sp. 1 (Pl. 4, Fig. 1).

\section{Site 401 (Figure 2)}

Paleocene and Eocene faunas are better represented than in the previous hole (400A). There appear to be two successive faunal assemblages: the first, dating from the Paleocene and the early Eocene, contains Bythocytheromorpha, sp. 1, Monoceratina tricuspidata Jones and Hinde in Deltel, 1961, Cytherella consueta Deltel (Pl. 1, Fig. 1), Bairdia cymbula Deltel (Pl. 1, Figs. 8, 9), Agrenocythere sp. 1 (Pl. 2, Fig. 7); the second, dating from the middle and late Eocene and the early Oligocene, is richer and more diversified and contains Cytherella transversa Speyer (Pl. 1, Fig. 2), Argilloecia angulata (Deltel) (Pl. 5, Fig. 6), Koilocythere sp. 1 (Pl. 5, Fig. 4), Cardobairdia sp. 2 (PI. 1, Fig. 7), Trachyleberidea prestwichiana (Jones and Sherborn) (PI. 2, Fig. 8), and various species of Krithe, Parakrithe, Cytherella, and Bair-

\begin{tabular}{|c|c|c|c|c|}
\hline 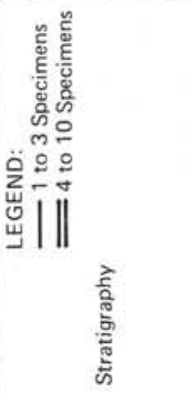 & نั & 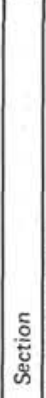 & 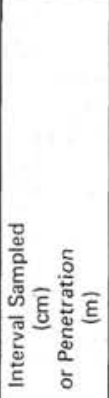 & 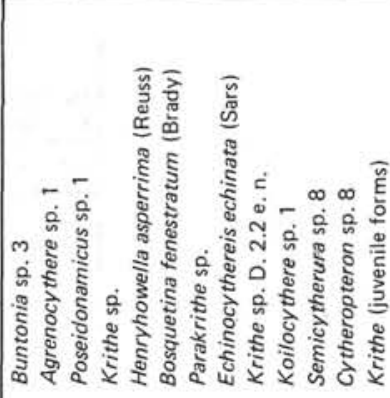 \\
\hline \multirow{2}{*}{ Quaternary } & 1 & 1 & 68.70 & \\
\hline & 2 & 2 & $114-116$ & \\
\hline Late Pliocene & 3 & 4 & 54.56 & \\
\hline \multirow{6}{*}{ Early Pliocene } & \multirow[b]{2}{*}{12} & 2 & $60 \cdot 62$ & \\
\hline & & 5 & $60-62$ & \\
\hline & \multirow{2}{*}{13} & \begin{tabular}{|l|}
4 \\
\end{tabular} & 64.66 & \\
\hline & & CC & & \\
\hline & \multirow{2}{*}{14} & \begin{tabular}{|l|}
3 \\
\end{tabular} & $22-24$ & \\
\hline & & $\mathrm{CC}$ & 207.5 & \\
\hline \multirow{6}{*}{ Late Miocene } & 16 & 1 & 143.145 & \\
\hline & 17 & $\mathrm{CC}$ & & \\
\hline & \multirow{2}{*}{18} & \begin{tabular}{|l|}
2 \\
\end{tabular} & 81.83 & \\
\hline & & \begin{tabular}{|l|}
3 \\
\end{tabular} & $52-54$ & \\
\hline & 21 & CC & 275 & \\
\hline & 24 & \begin{tabular}{|l|}
6 \\
\end{tabular} & 67.68 & \\
\hline \multirow{5}{*}{ Middle Miocene } & \multirow{2}{*}{29} & \begin{tabular}{|l|}
1 \\
\end{tabular} & $114-116$ & \\
\hline & & $\mathrm{CC}$ & 351 & \\
\hline & 32 & CC & 379.5 & \\
\hline & 34 & $\mathrm{CC}$ & & \\
\hline & 35 & \begin{tabular}{|l|}
3 \\
\end{tabular} & $103-105$ & \\
\hline \multirow{4}{*}{ Early Miocene } & & 1 & 44.46 & \\
\hline & 37 & 4 & 72.74 & \multirow{4}{*}{ broken ostracodes undetermined } \\
\hline & 39 & 1 & $117 \cdot 118$ & \\
\hline & 40 & 1 & $22-25$ & \\
\hline Middle Eocene & 49 & 1 & $75-78$ & \\
\hline \multirow{3}{*}{ Early Eocene } & 54 & $\mathrm{CC}$ & & \\
\hline & 55 & $\mathrm{CC}$ & & \\
\hline & 56 & 2 & $60-63$ & \\
\hline \multirow{2}{*}{ Late Paleocene } & 57 & \begin{tabular}{|l|}
2 \\
\end{tabular} & $4-7$ & \\
\hline & 58 & $\mathrm{CC}$ & & \\
\hline Middle Paleocene & 59 & 1 & $5 \cdot 7$ & \\
\hline
\end{tabular}

Figure 1. Tertiary ostracode species at Hole 400A.

dia. We did not observe any change between the Eocene and Oligocene faunas. Many deep-water forms are comparable to those known from the Paleogene in the southern part of the Aquitaine Basin and in the Gulf of Gascony (Deltel, 1961; Ducasse, 1974, 1975, in press). In the Quaternary sediments only a few Krithe persist.

\section{Holes 402/402A (Figure 3)}

These two holes provided few samples and little fauna. We noted the presence of a deep-water Eocene form, Bairdia sp. 6 (Pl. 2, Figs. 1, 2), common to both Sites 401 and 402 . The 


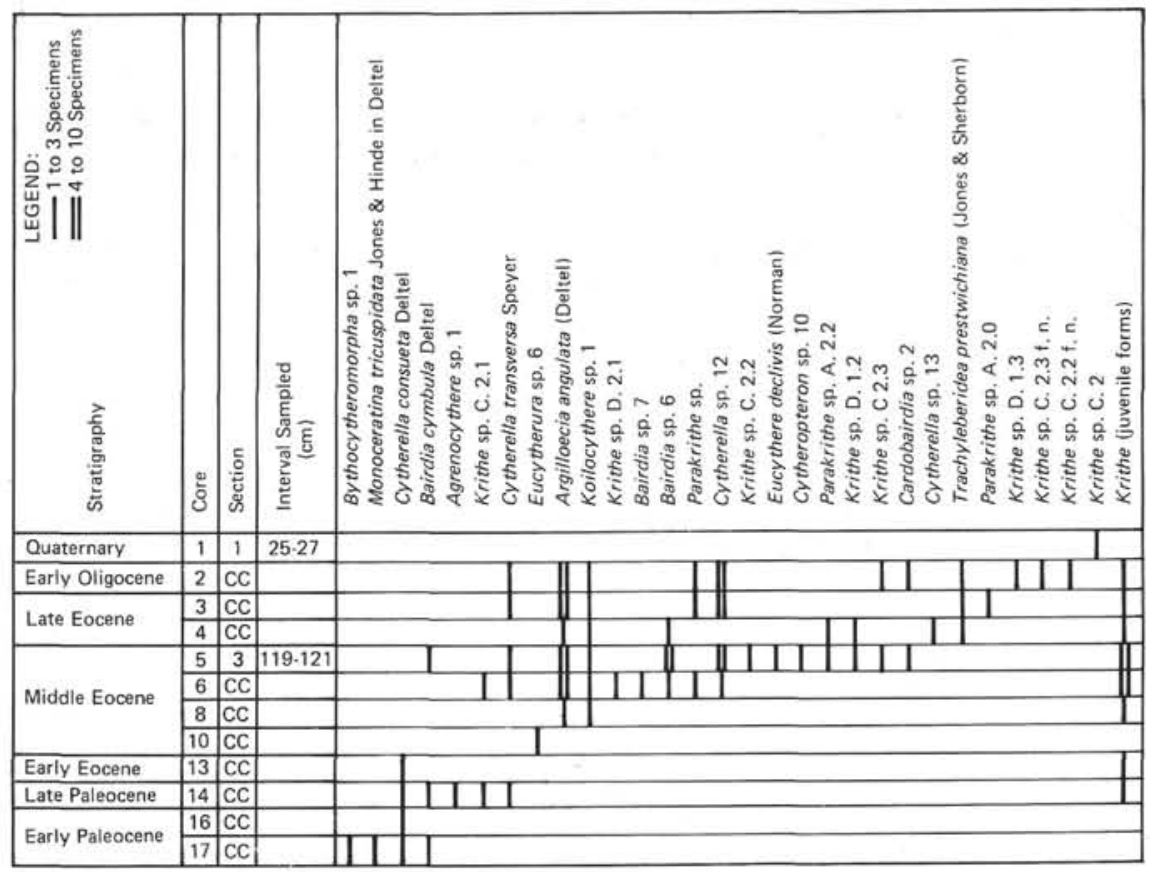

Figure 2. Tertiary ostracode species at Site 401.

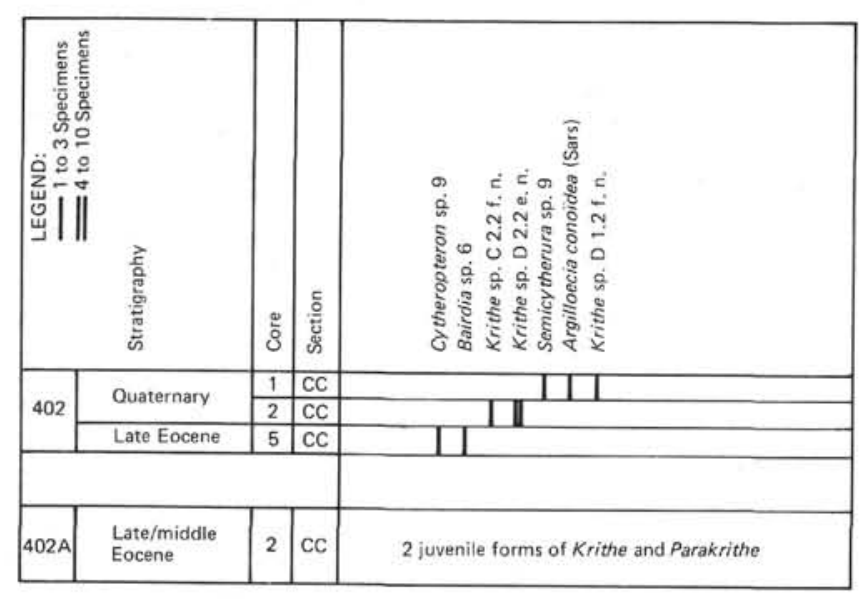

Figure 3. Tertiary ostracode species at Holes 402/402A.

same species is found on the southern margin of the Gulf of Gascony, on the continental plateau of northern Spain, east of the Santander Canyon. Krithe is predominant in the Quaternary sediments.

\section{Southwestern Margin of the Rockall Plateau}

\section{Site $\mathbf{4 0 3}$ (Figure 4)}

The Eocene fauna is poor and almost all of its constituents are represented on the northern margin of the Gulf of Gascony. From the upper Miocene a new fauna, relatively rich and diversified, is progressively established. It is essentially composed of Henryhowella asperrima (Reuss), Bradleya dictyon (Brady) (Pl. 3, Fig. 9), Poseidonamicus sp. 1 and Krithe, with less frequently, Agrenocythere sp. 1, Bardia sp. 1 Moyes (Pl. 1, Fig. 10), Cytheropteron sp. 26 (Pl. 5, Fig. 3), Echinocythereis echinata (Sars) (P1. 2, Fig. 11), and Thalas- socythere acanthoderma (Brady) (Pl. 3, Fig. 4). During the upper Pliocene and the Quaternary, this fauna is considerably depleted.

\section{Site 404 (Figure 5)}

The fauna is poor. As at Site 403, a new fauna appears above the unconformity that separates the Eocene-Miocene; it declines during the Plio-Quaternary. The main forms encountered in the Eocene sediments are Hermanites (?) (Pl. 3, Figs. 7, 8), Paracypris (Pl. 5, Fig. 8), Parakrithe, and Loxoconcha (Pl. 4, Fig. 3). This is a different association from that encountered at Site 403. From the Miocene, Henryhowella asperrima (Reuss), Cytherella consueta Deltel, Krithe and Poseidonamicus sp. 1 are characteristic. Almost all of these forms are found at Site 403. Plio-Quaternary sediments contain only Poseidonamicus.

\section{Site 405 (Figure 6)}

As at Sites 403 and 404 , the fauna changes after the Eocene but remains richer into the Quaternary. The lower Eocene fauna is meager; consisting of Cytherella consueta Deltel and a small form of Krithe sp. E 1-2. The middle Eocene fauna is more varied, with the addition of Hazelina sp. 5 (Pl. 2, Fig. 9), Trachyleberidea prestwichiana (Jones and Sherborn), Atlanticythere (Pl. 3, Fig. 2), Bythocypris (Pl. 2, Fig. 4), and Bairdia (Pl. 2, Fig. 3) to the two already existing species. It differs from that of Sites 403 and 404. From the lower Pliocene the fauna is comparable to that found at Site 403. It is at Site $\mathbf{4 0 5}$ that the Quaternary fauna is most complete, comprising in particular Poseidonamicus sp. 1, Henryhowella asperrima (Reuss), Bradleya dictyon (Brady), and Thalassocythere acanthoderma (Brady), together with two new forms, Oxycythereis dorsoserata (Pl. 3, Fig. 3) and unidentified genus 3 (Pl. 5, Fig. 9). 


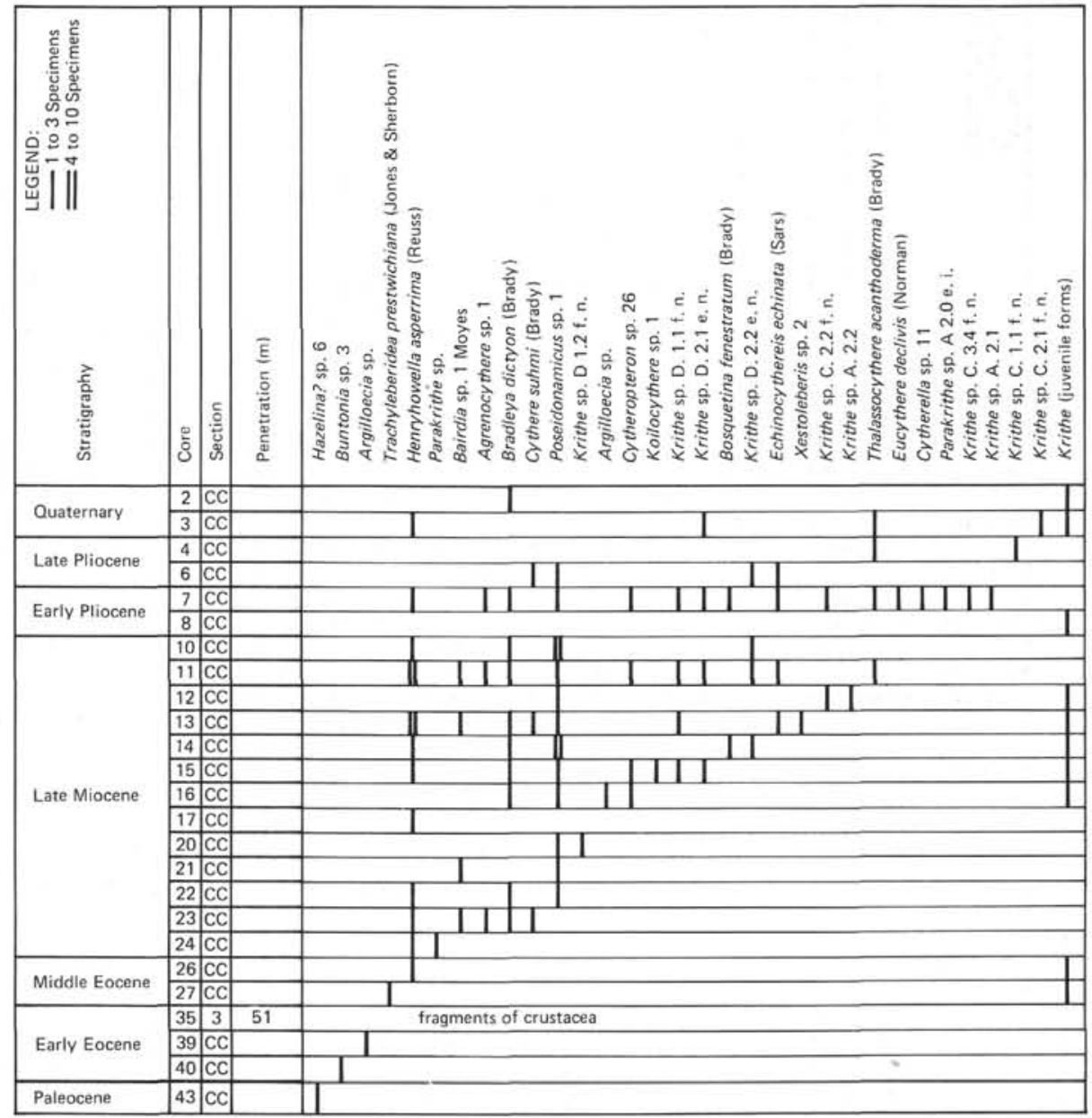

Figure 4. Tertiary ostracode species at Site 403.

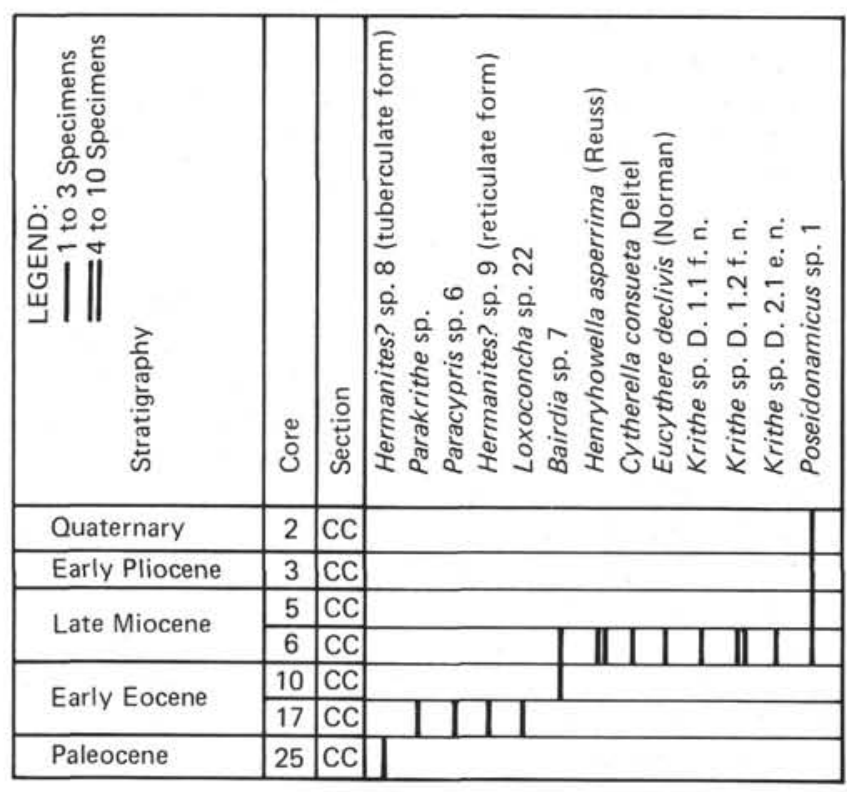

Figure 5. Tertiary ostracode species at Site 404.

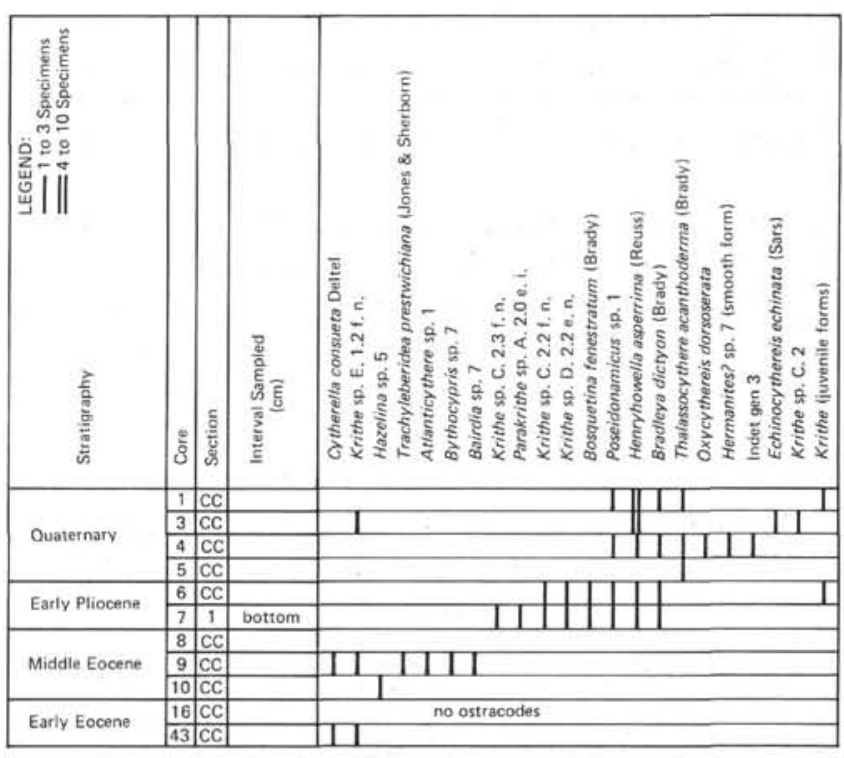

Figure 6. Tertiary ostracode species at Site 405. 


\section{Site 406 (Figure 7)}

The most distinctive characteristics observed at this site are a greater homogeneity of the fauna down section and an earlier appearance of Poseidonamicus sp. 1 in the upper Eocene. During the Quaternary the unidentified genus 3 previously noted at Site 405 is again present.

\section{DISCUSSION OF HYPOTHESES}

Because each faunal assemblage reflects an ecological setting whose depth variable can be evaluated, analysis of their succession should demonstrate the evolution of the depth level at the site through time. Variations in the microfauna of deep environments in terms of its nature and density make it possible to follow not only the paleoecological evolution of the sites, but also circulation patterns in the bathyal and abyssal regions. Furthermore, the geographic distribution of forms leads to the definition of paleobiogeographic zones.

\section{PALEOBATHYMETRY}

\section{Northern Continental Margin of the Bay of Biscay (Fi-} gure 8)

In Hole 400A, the ostracode microfauna shows the area to have been a deep region from as early as the Paleocene. The exclusive presence of juvenile forms of Krithe indicates an environment where conditions of life were difficult; the appearance of Agrenocythere suggests that the depth was over 2,000 meters, probably close to that of the site today. This interpretation appears to be corroborated by the nature of the faunal association which develops from the lower Miocene up to and including the Quaternary. The fauna is poor, of low diversity, and is dominated by the genera Krithe and Henryhowella. This type of fauna is encountered at the present time in the abyssal environments in the Gulf of Gascony at depths of between 3500 to 4500 meters

\begin{tabular}{|c|c|c|c|}
\hline 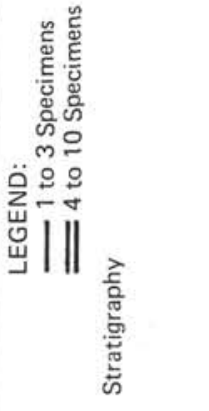 & రัँ & 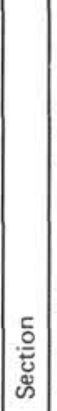 & 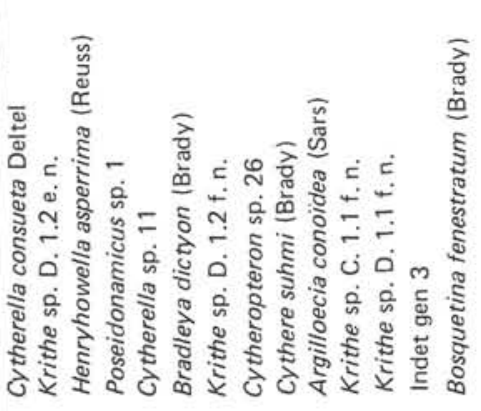 \\
\hline Quaternary & 1 & cc & \\
\hline Early Pliocene & 3 & CC & \\
\hline \multirow{3}{*}{ Upper Miocene } & $\frac{4}{5}$ & $\mid$ & \\
\hline & 8 & CC & \\
\hline & 13 & & \\
\hline Middle Miocene & 16 & $\mathrm{CC}$ & \\
\hline Middle Oligocene & 35 & $\mathrm{cc}$ & \\
\hline \multirow{2}{*}{ Late Eocene } & 36 & CC & \\
\hline & 42 & & \\
\hline
\end{tabular}

Figure 7. Tertiary ostracode species at Site 406.
Site 401 has been a deep area since the Paleocene. The fauna is richer and more diversified than at the previous site, implying less severe conditions in the environment. The simultaneous presence of Bairdia cymbula Deltel, Monoceratina tricuspidata Jones and Hinde, Bythocytheromorpha, Agrenocythere, and Cytherella consueta Deltel indicates a depth analogous to that of the present at about 2000 meters.

From the few samples from Holes 402 and $402 \mathrm{~A}$ it is difficult to provide bathymetric details, but the fauna that has been recovered indicates a deep environment. The presence of Parakrithe sp. A in the upper Eocene, in a form identical to that found at the previous site, suggests that both sites were situated at the same level in depth.

In short, then, it appears that as early as the Paleocene the continental margin of North Gascony was among the deep zones and moreover, that Site 400 was already situated much lower than Sites 401 and 402.

\section{Rockall Area (Figure 9)}

At Site 403 the forms from upper Paleocene (Core 43) are typical of a continental platform area, but the lower Eocene ostracodes indicate that the depth increased very rapidly (Cores $40,39,35)$, probably to upper bathyal depths $(500 \mathrm{~m})$. In the middle Eocene the presence of Trachyleberidea prestwichiana (Jones and Sherborn) attests to an infra-bathyal environment (depth $>1000 \mathrm{~m}$ ). In the upper Miocene, the presence of Agrenocythere, Bradleya, Poseidonamicus, and Echinocythereis, associated with numerous Krithe, implies that the present-day depth of the site (2371 meters) had been reached.

At Site 404 during the Paleocene (Core 25), the presence of Hermanites (?) sp. 8, possessing a noticeable eye tubercule, suggests that the environment was that of a continental shelf (depth $<150 \mathrm{~m}$ ). However, the mixture of forms characteristic of the shelf (Cores 17 and 10) (Hermanites (?) and Loxoconcha) and species living in deeper zones (Bairdia and Parakrithe) encourages the belief that the setting was upper bathyal (about 200-500 m). Loxoconcha is an allochthonous form never found in the upper bathyal zone. The present-day depth of the site was reached in late Miocene time.

In short, the bathymetric evolution of Sites 403 and 404 was identical, from a continental shelf type at the end of the Paleocene to one of lower to middle bathyal depth in the middle Eocene.

At Site 405, in lower Eocene sediments, the ostracode fauna consists of Krithe sp. E-1-2 (a small form) and Cytherella consueta Deltel. It may represent a middle bathyal environment (500 to 1000 meters) deepened in the middle Eocene, as denoted by Atlanticythere, Trachyleberidea, Bythocypris, and Bairdia, which are deep-water ostracode genera. During the Pliocene, the site reached its present depth, as confirmed by the presence of Poseidonamicus sp. 1, Bradleya dictyon (Brady) and Bosquetina fenestratum (Brady) in the fauna.

Site 406, the upper Eocene (Core 42) fauna consists of Krithe sp. D2-2 (a large form) and Cytherella consueta Deltel, indicating a middle to lower bathyal environment. From the end of late Eocene time, the presence of 


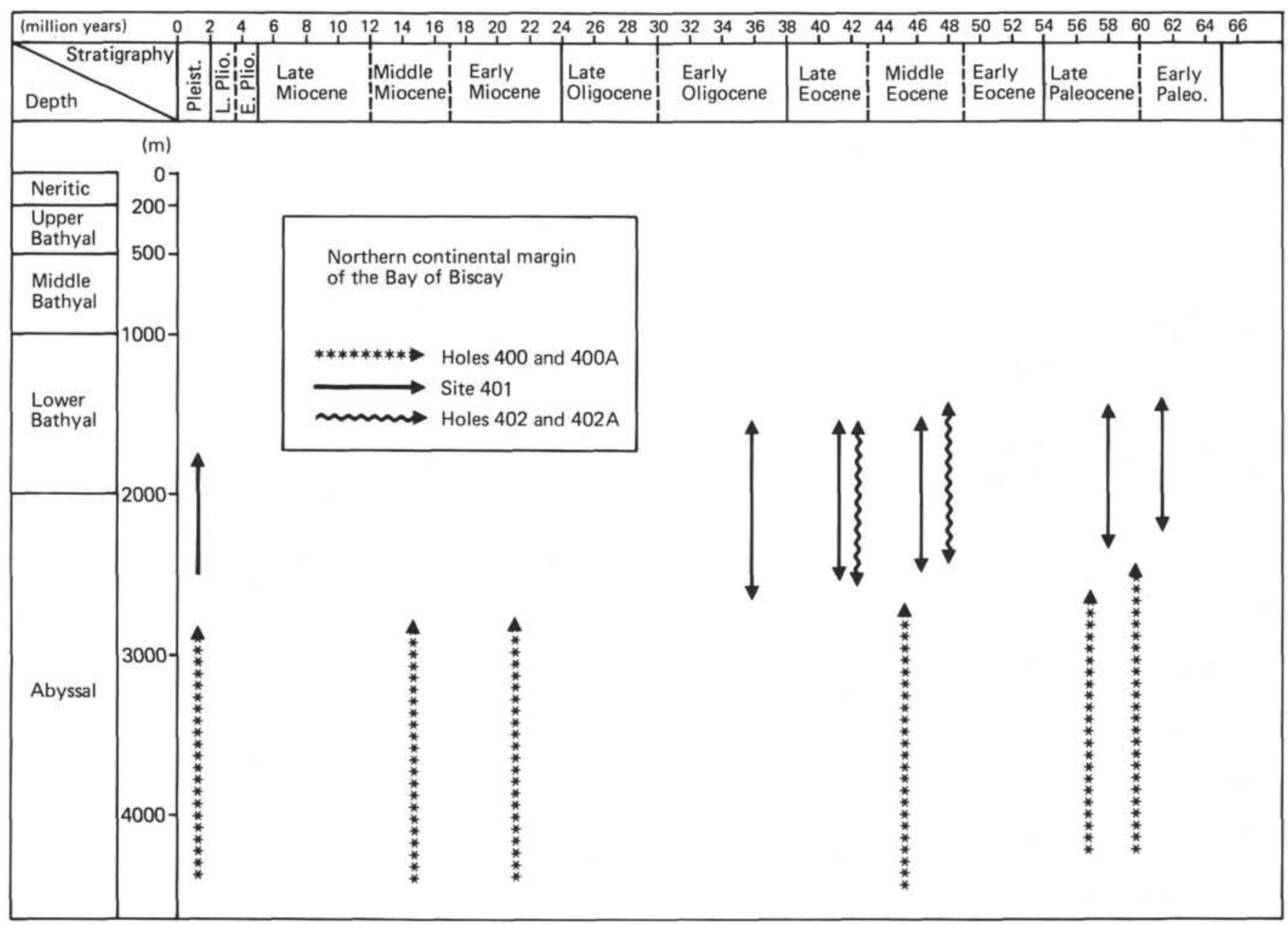

Figure 8. Estimated depth of sites: Northern continental margin of the Bay of Biscay.

Poseidonamicus and Henryhowella bear witness to a depth comparable to that of the present day.

As at the two previous sites (403 and 404), a pronounced subsidence occurred at the beginning of the Paleogene, in particular between the lower and upper Eocene. It seems, moreover, that Sites 405 and 406 were at a deeper level at this period than Sites 403 and 404.

Comparison of the depths estimated for the sites in the southwestern area of the Rockall Plateau and those of Sites 116 and 117 (Leg 12) of the Hatton-Rockall Basin (Benson, 1972; Laughton and Berggren, 1972) shows that the physiography of this region as we know it was roughly sketched out at the beginning of the Tertiary (Figure 10); it appears that, in Paleocene/early Eocene time, the Hatton-Rockall Basin had already formed (Sites 116/117 were characteristic of upper bathyal depths, 200-500 m). This internal depression had an outlet channel towards the south represented by Helm's Deep (Site 405) in which the depth was approximately 500 to 1000 meters. On the northwestern side of this trough a continental platform environment had grown up but it quickly became subsident.

It thus appears that the principal phase of deepening on the southern border of the Rockall Plateau area occurred during the Eocene. These conclusions are in accordance with those of Benson (1972) for Sites 116 and 117 in the area of the
Hatton-Rockall Basin, further to the north. In comparison with the more northerly part, the southwestern area seems, from the depth estimates, to have been tilted.

\section{PALEOCIRCULATION AND WATER-MASS STRUCTURE}

\section{The Origin of Modern Deep Circulation}

The composition of deep-water ostracode populations in the Rockall and the Bay of Biscay areas changes markedly at the end of the upper Eocene at Site 406 at Rockall and somewhat later in the Bay of Biscay.

During early Tertiary the deep-water ostracode fauna includes many genera such as Cytherella, Bairdia, Monoceratina, Argilloecia, Cardobairdia, Atlanticythere, and Trachyleberidea which become scarce or disappear during late Tertiary. Moreover, at the end of the Eocene and in the Oligocene, genera such as Poseidonamicus, Bradleya, Agrenocythere, and Bosquetina, representing the "modern" fauna of today, cosmopolitan in character, make their appearance. This fauna has been called " psychrospheric', by Benson and Sylvester-Bradley (1971) because it lives in "cold" deep-water zones $\left(\mathrm{T}^{\circ}<8^{\circ}-10^{\circ} \mathrm{C}\right)$. Benson (1975) suggests that its appearance marks the beginning of a progressive 


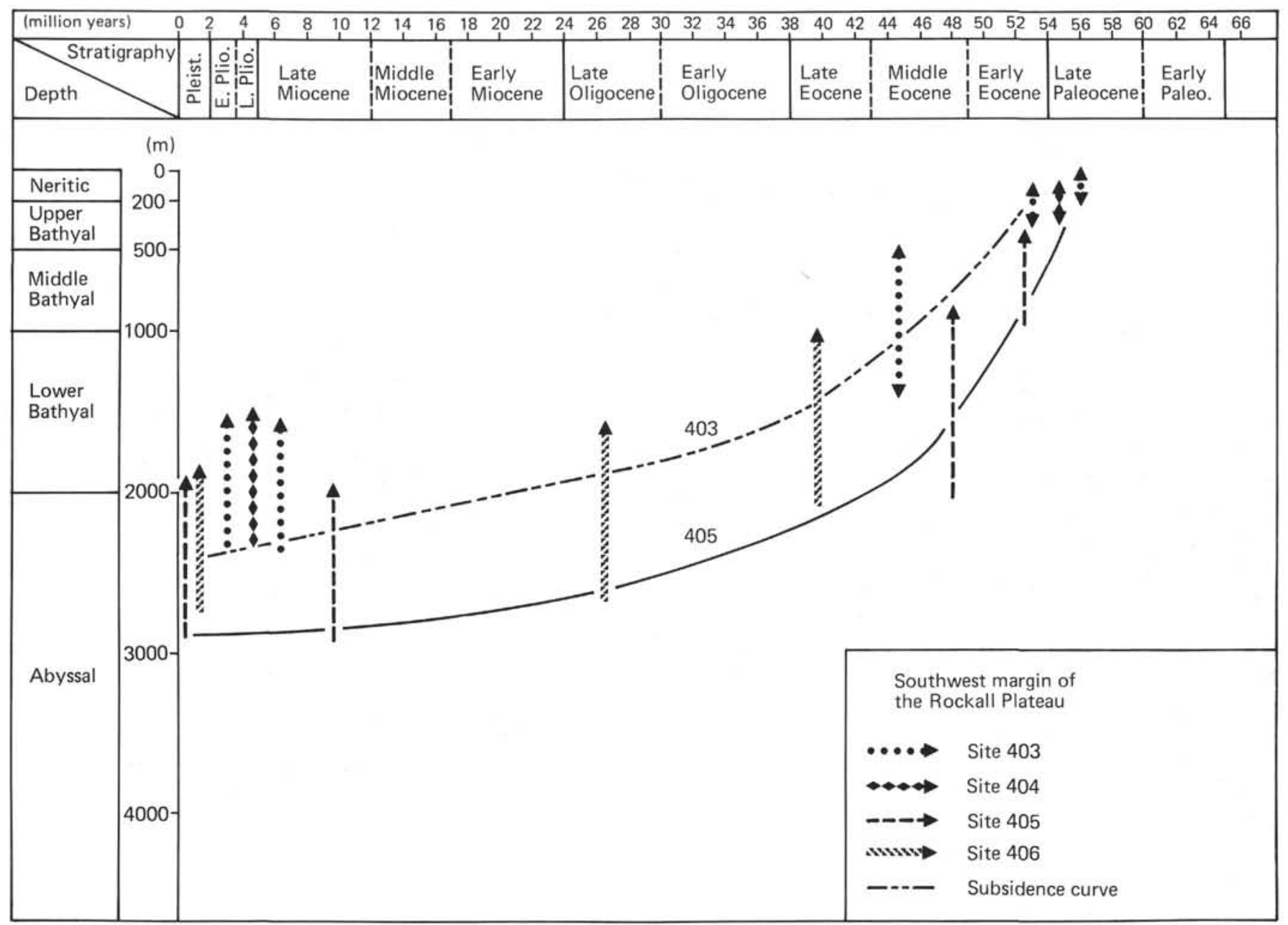

Figure 9. Estimated changes in depth of sites on the southwest margin of the Rockall Plateau.

transformation of the "thermospheric", ocean to a "psychrospheric" ocean and thus a significant cooling of the waters of the ocean bed. We would opt for the same interpretation for Site 406 at Rockall.

It is contended that, towards the end of late Eocene/early Oligocene time, an extensive glaciation developed in the Antarctic regions (Devereux, 1967; Kennett et al., 1975; Shackleton and Kennett, 1975). This cooling could have been responsible for the arrival of cold deep water from the Southern Hemisphere, according to the classic model for deep-sea circulations as defined by Stommel (1958), Stommel and Arons (1960a, b). However, we think that an equivalent flow of northern origin would provide a possible explanation for the cooling, for the Arctic Sea was opened at that time. The Norwegian Sea, formed by the separation of Greenland and Scandinavia at the beginning of the Eocene (Harland, 1969; Vine and Hess, 1971), was already in existence and the Faroe Iceland Ridge was submerged by middle Eocene (Doche, 1976). Because the subsidence at Rockall was already well advanced by late Eocene time (see Paleobathymetry, this paper) there was no longer anything to prevent the opening of cold, deep-water hydrologic relations between the northeast Atlantic and the Arctic/Norwegian Sea complex. Knowledge of the deep ostracode fauna of the Norwegian Sea in Tertiary time could prove or disprove the hypothesis of an Arctic influence at Rockall.
It should be noted that this psychrospheric environment is not to be found in the Bay of Biscay at the same period (Site 401). The deep-water fauna at this site at the end of the Eocene and the beginning of early Oligocene time is unquestionably of thermospheric type (Figure 11). This is not surprising because the area is further south and is out of the line of the "classic roads" of deep-ocean circulations from the north (Norwegian Sea) as shown in the circulation models defined by Worthington (1970) and Berggren and Hollister (1974).

These results obtained for the northeastern Atlantic may be compared to those of Benson (1975) who showed that in the South Atlantic (DSDP Leg 3) the psychrosphere was established at more or less the same time.

This is unquestionably a most important hydrological event in deep-sea circulation in the North Atlantic, and may be considered as the prime factor in the evolution and change of the benthic deep-sea ostracodes at the close of Eocene time because, in addition to the variation in temperature, which in itself is fundamental, there is no doubt that the bottom waters coming from the Norwegian Sea had different physicochemical properties from those of the northwestern Atlantic and were capable of additionally influencing the morphological evolution of genera.

Without underestimating the role of tectonic activity, which may cause sedimentary hiatuses, it is also possible that 


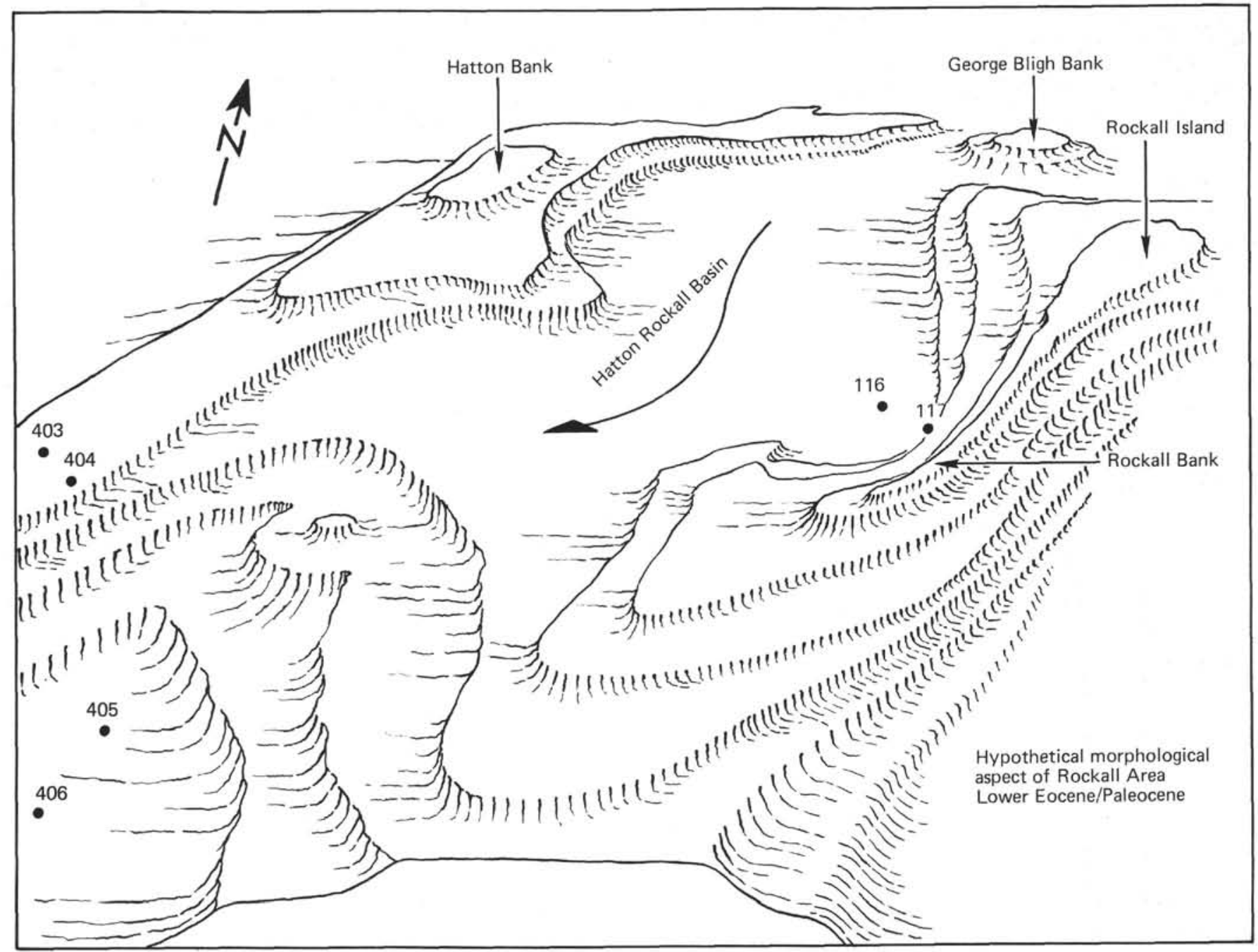

Figure 10. Hypothetical morphological aspect of Rockall area. Lower Eocene/Paleocene.

a strong deep-ocean circulation at this time may have been responsible for a number of breaks in sedimentation in the region, such as the absence of lower Oligocene strata at Sites 403404,405 , and 406, and the poor development of sedimentation in the Oligocene area.

\section{Paleogene Changes in Water Circulation in Lower and Upper Levels}

The establishment of the psychrosphere is certainly the major event in the deep-sea environment in the northeast Atlantic, but the analysis of the ostracode microfauna reveals other important hydrologic events. At Site 401, in the deep thermospheric environment, two quite distinct groups make up the Tertiary faunal association. At the base (Cores 17 to 10 , lower Paleocene-lower mid-Eocene) the fauna is relatively poor and little varied whereas at the top (Cores 8 to 2, lower mid-Eocene to lower Oligocene) it becomes abundant and shows a great diversity of species.

In a deep-sea environment, specific diversity and the numerical significance of individuals in an ostracode assemblage are directly related to the availability of food, mainly provided by marine plankton which falls into the bottom (Peypouquet, doctoral thesis, in preparation). The presence of Parakrithe sp. A above Core 8 implies a setting where $\mathrm{P}$ ions were relatively abundant, which calls for a large supply of organic material. The presence of Krithe sp. C 2-3 and Parakrithe sp. A 2-2 which are species having a wide vestibulum, suggests a slight lowering of the dissolved $\mathrm{O}_{2}$ by the organisms living in the benthos. Lithological analysis demonstrates the presence of pyrite in the highly carbonated sediment, rich in nannoflora, and confirms the existence of a "reducing" environment and the ample supply of organic matter. Consequently, it appears that in the Bay of Biscay the circulatory processes on the ocean bottom, and probably on the surface, were modified between the lower and middle Eocene. Perhaps the orogenesis of the Pyrenees, which dates from the same period, may have been implicated in this hydrologic change. The gaps in sedimentation in Sites 118 and 119 (Laughton and Berggren, 1972) in the Bay of Biscay, contemporary with the above-mentioned events, give support to this hypothesis.

\section{Neogene Stability}

Other periods during the Tertiary are marked by an abundance and variety of deep-water ostracodes, for example, the late Miocene and early Pliocene. As on the North Gascony 


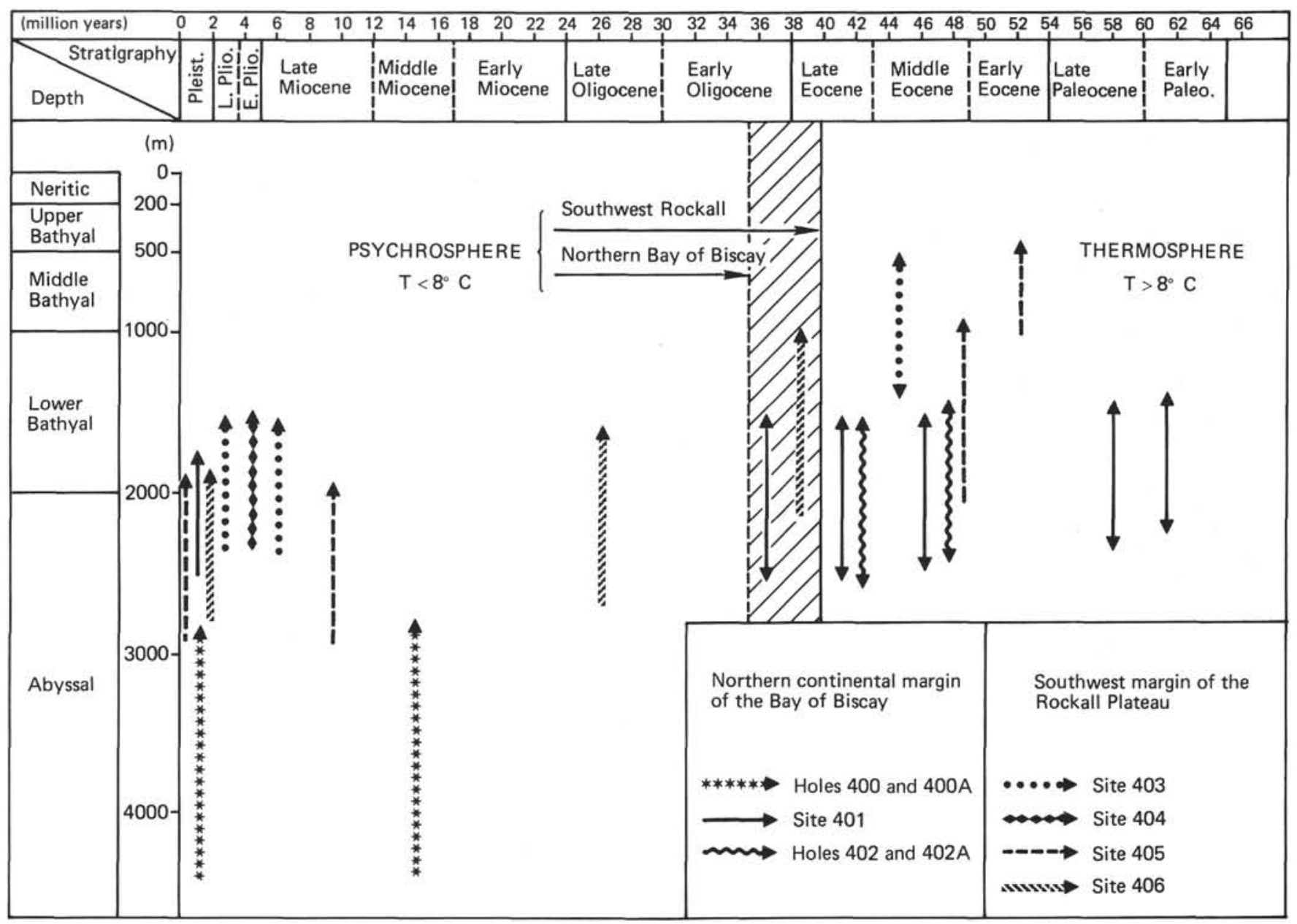

Figure 11. The beginnings of the psychrosphere.

margin, Parakrithe sp. A makes its appearance in late Eocene time, indicating an enrichment in $\mathrm{P}$ ions in the deep-ocean environment. These observations apply in particular at Sites 403 and 405 at Rockall. It is possible that during these episodes the bottom currents were of low intensity, and the supply of organic plankton enriched the level of nutrition in the surroundings and stimulated benthic activity. These episodes are marked by fairly extensive pelagic sedimentation.

\section{The Glacial Interval}

With the onset of glacial phenomena, at the transition from lower to upper Pliocene (Berggren, 1972), a re-intensified flow in the circulation in the deep ocean is attested, in some cases by a hiatus in the upper Pliocene section (Sites 401 , 404,405 , and 406), in others by a marked impoverishment in the deep-water fauna of the upper Pliocene (Site 403). At the latter site the lower Pliocene fauna (Core 7) is extremely rich and varied (16 species) whereas the upper Pliocene (Cores 6 and 4) shows a sparse fauna (4 species). Deep-water midTertiary forms (Bradleya, Agrenocythere, Argilloecia, Parakrithe, and Poseidonamicus) decline or disappear, and are replaced by other, better adapted genera (Krithe, Cytheropteron, Thalassocythere, Echinocythereis, and Bosquetina). This phenomenon in the Rockall Basin has already been commented upon (Peypouquet, 1975b). The cause is essentially hydrologic. The arrival of cold waters $\left(\mathrm{T}^{\circ}<3^{\circ} \mathrm{C}\right)$, very poor in nutrients, especially $\mathrm{Si}$ and $\mathrm{P}$, is implicit in the theory that the Norwegian Sea operated as a Mediterranean Sea, as understood by Worthington (1970). This milieu is unfavorable to many species and caused a partial change in the fauna. The flow of Norwegian waters with their different physico-chemical characteristics encouraged evolution in the deep ostracode faunas.

\section{BIOGEOGRAPHY}

Comparative analysis of the ostracode fauna of the entire group of Leg 48 sites provides other insights. The deep-water forms of the Paleogene (Bairdia cymbula Deltel, Argilloecia angulata [Deltel], Cytherella consueta Deltel, Cytherella transversa Speyer, and Trachyleberidea prestwichiana [Jones and Sherborn]) on the northern continental margin of the Bay of Biscay are very similar to those of southern Aquitaine Basin (Deltel, 1961; Ducasse, 1974, 1975, in press). Some of these forms, in particular Bairdia cymbula, seem not to develop in the northeastern areas of Rockall. There, genera such as Atlanticythere and some species of Hazelina unknown in Aquitainia areas occur. The two areas, considered as deep-water biogeographical zones, have different ecological variables. This difference persisted into the Quaternary; Poseidonamicus and Bradleya are practically 
non-existent in the Bay of Biscay at the present time, but are well represented in the North Atlantic.

The geographical setting of the two areas obviously plays some part in determining their peculiarities, but the deciding influence is most likely hydrology. Rockall is directly involved in the constant exchanges between the northeastern Atlantic and the Norwegian Sea, whereas the Bay of Biscay is slightly offset in relation to the ocean routes and lessdirectly influenced by northern elements. In the Tertiary, the Bay of Biscay and its northern margin were dependent on water which came from the Tethys or in the Quaternary, from the Mediterranean Sea (Peypouquet, 1973; Le Floch, 1968, 1969). As a result, the physico-chemical conditions of the deep-sea environment in these two areas, supplied as they are by two different sources, were dissimilar and gave rise to two distinct biogeographical provinces.

\section{CONCLUSIONS}

Analysis of the distribution in time and space of the deepsea ostracodes in the northeastern Atlantic takes account of the major paleogeographical and paleohydrological events (Figure 12).

At the beginning of the Tertiary, the northern continental margin of the Bay of Biscay was already a deep zone; it had undoubtedly reached its present depth. In the Paleocene, Site 400 had already reached a greater depth than Sites 401 and 402 and the conditions for benthic life were unfavorable.

In the Eocene, the southwestern margin of the Rockall Bank subsided markedly and the general physiography of the Rockall area was outlined. The establishment of the psychrospheric environment came into being by the end of late Eocene time at Rockall, and later, after the beginning of the Oligocene, in the Bay of Biscay. This phenomenon was the deciding factor in the renewal and expansion of the ostracode fauna. An increase in the intensity of bottom currents probably played a part in the sedimentary hiatus observed in the lower Oligocene at Rockall.

A major hydrologic transition occurred between the lower and middle Eocene in the Bay of Biscay, as evidenced by the increase in benthic productivity during middle Eocene up to lower Oligocene time. Decreases in the dissolved $\mathrm{O}_{2}$ content on the bottom occurred during this period. Upper Miocene and lower Pliocene times appear as periods of distinct slackening in the deep-ocean circulation from the north. The principal influence of bottom currents came from the Norwegian Sea at the beginning of upper Pliocene time, contributing to the evolution of deep-water ostracode faunal assemblages and affecting sedimentation (hiatuses, condensed sequences).

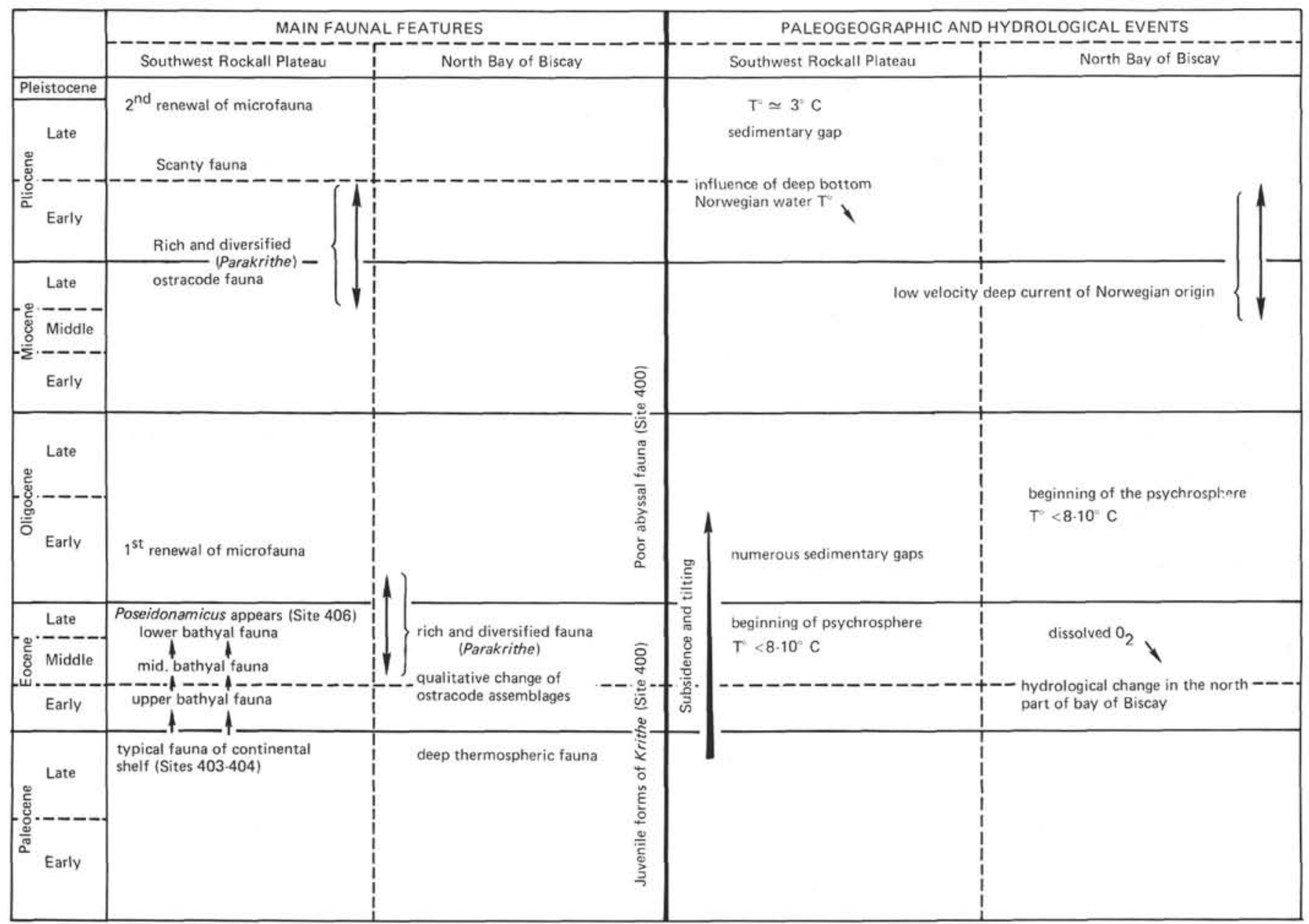

Figure 12. Main faunal features and paleogeographic and circulation events in the northern continental margin of the Bay of Biscay and southwest margin of the Rockall Plateau. 
Finally, it appears that the northern continental margin of the Bay of Biscay and the Rockall area were, from the beginning of the Tertiary to the present time, two distinct ocean zones, each undergoing the influence of masses of deep water of separate origin, and are therefore two individual biogeographical areas.

\section{ACKNOWLEDGMENTS}

We would like to thank L. Montadert and D. G. Roberts for the opportunity to study the samples from DSDP Leg 48 . We are indebted to J. Moyes for his comments and discussions during the study and R. H. Benson for his critical review of the manuscript. The stereophotographic illustrations of the specimens were made at S.N.E.A. (P) PAU.

\section{REFERENCES}

Benson, R. H., 1972. Preliminary report on the ostracods of Holes 116-117A. In Laughton, A. S., Berggren, W. A., et al., Initial Reports of the Deep Sea Drilling Project, v. 12: Washington (U.S. Government Printing Office), p. 427-432. 1 tabl., 3 fig., $2 \mathrm{pl}$.

, 1975. The origin of the psychrosphere as recorded in changes of deep sea Ostracodes assemblages, Lethaia, v. 8, p. 69-83.

Benson, R. H. and Sylvester-Bradley, P. C., 1971. Deep sea Ostracodes and the transformation of ocean to sea in the Tethys, Cent. Rech. PAU, SNPA Bull., p. 63-91.

Berggren, W. A., 1972. Late Pliocene-Pleistocene glaciation. In Laughton, A. S., Berggren, W. A., et al., Initial Reports of the Deep Sea Drilling Project, v. 12: Washington (U.S. Government Printing Office), p. 953-963.

Berggren, W. A. and Hollister, C. D., 1974. Paleogeography, paleobiogeography and the history of circulation in the Atlantic ocean. In Hay, W. (Ed.), Studies in paleo-oceanography. Spec. Publ. 20, p. 126-186

Deltel, B., 1961. Les Ostracodes du Paléogène moyen et supérieur d'Aquitaine méridionale, Thèse de Troisiéme cycle, Bordeaux, no. 95 , p. 215

Devereux, I., 1967. Oxygen isotope measurements of New Zealand Tertiary fossils, New Zealand J. Sci., v. 4, p. 988-1007.

Doche, J. L., 1976. Les hiatus de sédimentation dans les forages du JOIDES-DSDP (Deep Sea Drilling Project-Océan Atlantique), D.E. A. Géol. dyn., Géol. Sci., p. 57.

Ducasse, O., 1974. La faune d'Ostracodes des différents domaines marins de l'Oligocène en Aquitaine méridionale, $C$. R. Somm. Soc. Géol. France, p. 7-9.

-1975 . Les associations fauniques d'Ostracodes de l'Eocène moyen et supérieur dans le Sud du bassin d'Aquitaine. Distribution schématique et valeur paléoécologique, Inst. Géol. Bassin Aquitaine Bull., no. 17, p. 17-26.

, in press. La faune d'Ostracodes des dépôts tertiaires du plateau continental dans la partie centrale du Golfe de Gas- cogne. Intérêt paléoécologique—relations avec le continent, International symposium on Ecology and Zoogeography of Recent and Fossil Ostracoda (Saalfelden Salzburg).

Harland, W. B., 1969. Contribution of Spitsbergen to understanding of tectonic evolution of North-atlantic region, Am. Assoc. Petrol. Geol. p. 817-852.

Kennett, J. P., Houtz, R. E., Andrews, P. B., Edwards, A. R., Gostin, V. A., Hajos, M., Hampton, M., Jenkins, D. G., Margolis, S. V., Ovenshine, A. T., and Perch-Nielsen, K., 1975. Cenozoic paleoceanography in the south west Pacific ocean, Antarctic glaciation and the development of the circum Antarctic current. In Kennett, J. P., Houtz, R. E., et al., Initial Reports of the Deep Sea Drilling Project, v. 29: Washington (U.S. Government Printing Office), p. 1155-1169.

Laughton, A. S. and Berggren, W. A., 1972. Initial Reports of the Deep Sea Drilling Project, v. 12: Washington (U.S. Government Printing Office).

Le Floch, J., 1968. Quelques propriétés des eaux d'origine méditerranéenne dans le Golfe de Gascogne, Trav. Cent. Rech. et Etudes Océanol., v. 7, p. 25-36.

, 1969. Sur la circulation de l'eau d'origine méditerranéenne dans le Golfe de Gascogne et ses variations à courte période, Cahiers Océano., no. 7, p. 633-661.

Peypouquet, J. P., 1973. Sur la présence d'espèces méditerranéennes au niveau des étages circalittoral et épibathyal de la zone de Cap Breton, Inst. Géol. Bassin Aquitaine Bull., v. 13, p. 143146.

, 1975a. Les variations des caractères morphologiques internes chez les Ostracodes des genres Krithe et Parakrithe. Relation possible avec la teneur en $\mathrm{O}_{2}$ dissous dans l'eau, Inst. Géol. Bassin Aquitaine Bull., v. 17, p. 81-88.

, 1975 b. Le renouvellement de la faune d'Ostracodes du Bassin de Rockall entre le Miocène et le Pleistocène supérieur. Intérêt paléohydrologique, B. S. G. F., no. 5, p. 886-896.

Shackleton, N. J. and Kennett, J. P., 1975. Late Cenozoic oxygen and carbon isotopic changes at DSDP Site 284. Implications for the glacial history of the northern hemisphere and Antarctica. In Kennett, J. P., Houtz, R. E., et al., Initial Reports of the Deep Sea Drilling Project, v. 29: Washington (U.S. Government Printing Office), p. 801-807.

Stommel, H., 1958. The abyssal circulation, Deep-Sea Res., v. 4, p. 149-184.

Stommel, H., Arons, A.B., 1960a. On the abyssal circulation of the world ocean I. A stationary planctory flow patterns on a sphere, Deep-Sea Res., v. 6, p. 140-154.

,1960b. On the abyssal circulation of the world ocean II. An idealized model of the circulation pattern and amplitude in ocean basins, Deep-Sea Res., v. 6, p. 234-250.

Vine, F. J. and Hess, H. H., 1971. Sea floor spreading. In Maxwell , A. E. (Ed.), The sea: New York (Interscience), v. 4, p. $587-$ 622.

Worthington, L. V., 1970. The Norwegian Sea as a Mediterranean basin, Deep-Sea Res., v. 17, p. 77-84. 


\section{PLATE 1}

Figure $1 \quad$ Cytherella consueta Deltel.

Left valve; Site 401, Sample 16, CC, early Paleocene.

Figure 2 Cytherella transversa Speyer.

Left valve; Site 401, Sample 14, CC, late Paleocene, $\times 60$.

Figures 3, $4 \quad$ Cytherella sp. 11.

3. Right valve; Site 403, Sample 7, CC, early Pliocene, $\times 50$.

4. Left vavlta; dorsal view, Site 403, Sample 7, CC, early Pliocene $\times 50$.

Figure $5 \quad$ Cytherella sp. 12.

Right valve; Site 401, Sample 2, CC, early Oligocene, $\times 110$.

Figure $6 \quad$ Cytherella sp. 13.

Left valve; Site 401, Sample 4, CC, late Eocene, $\times 110$.

Figure $7 \quad$ Cardobairdia sp. 2.

Carapace, right valve; Site 401, Sample 5-3, 119-121 $\mathrm{cm}$, middle Eocene, $\times 200$.

Figures 8, 9 Bairdia cymbula Deltel.

8. Right valve; Site 401, Sample 17, CC, early Paleocene, $\times 50$.

9. Left valve; Site 401, Sample 5, sect. 3, 119-121 $\mathrm{cm}$, middle Eocene, $\times 50$.

Figure $10 \quad$ Bairdia sp. 1 Moyes.

Left valve; Site 403, Sample 21, CC, late Miocene, $\times 50$. 


\section{PLATE 1}
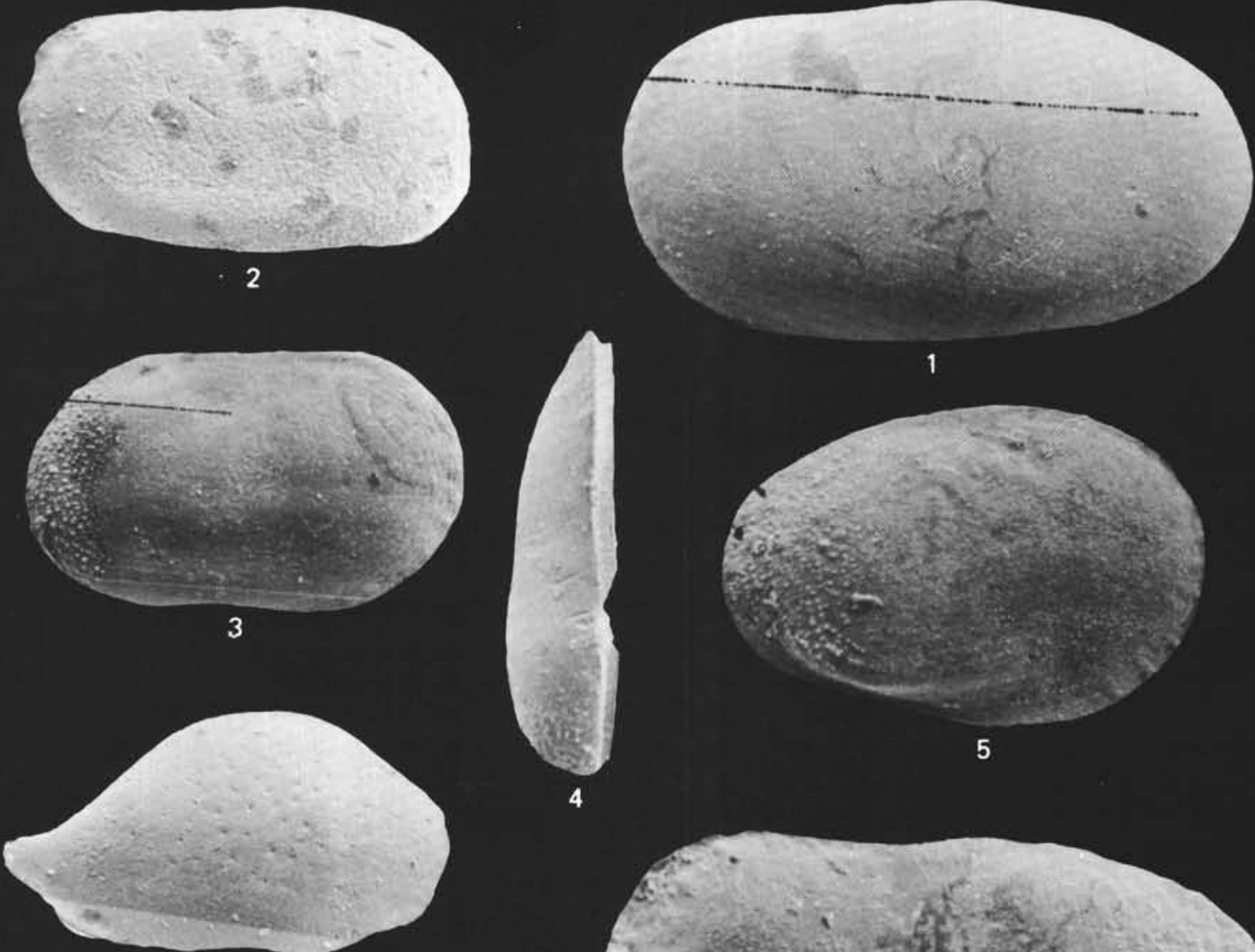

5

4
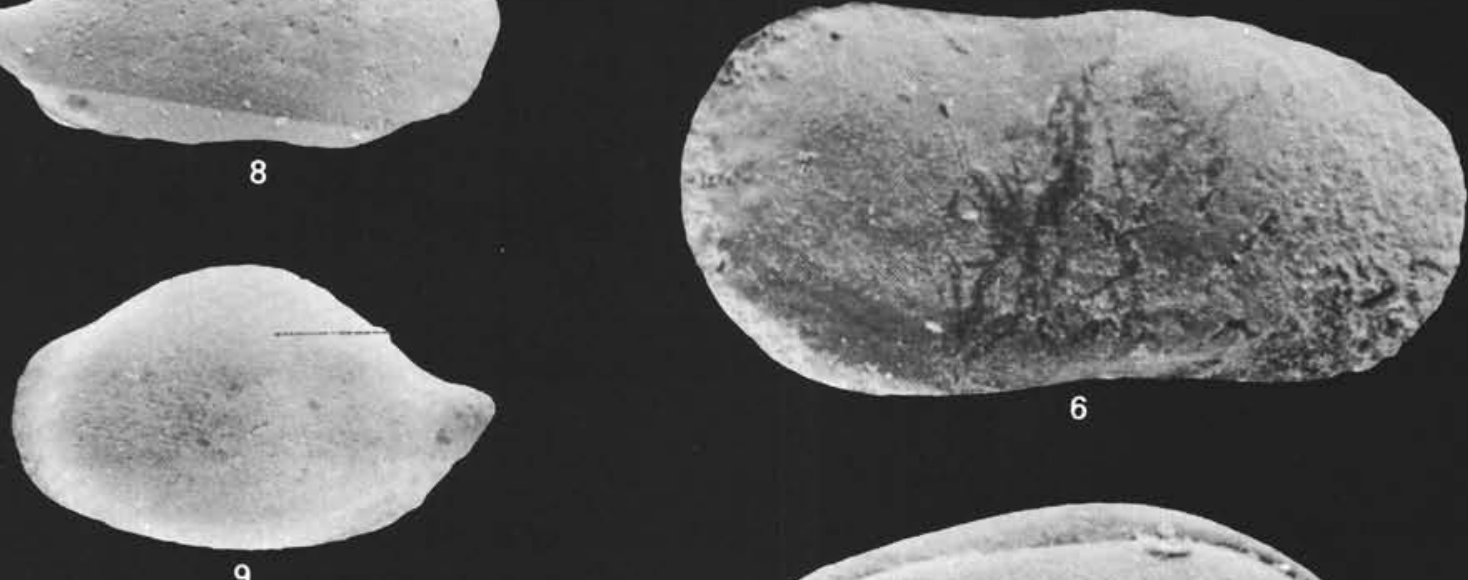

6
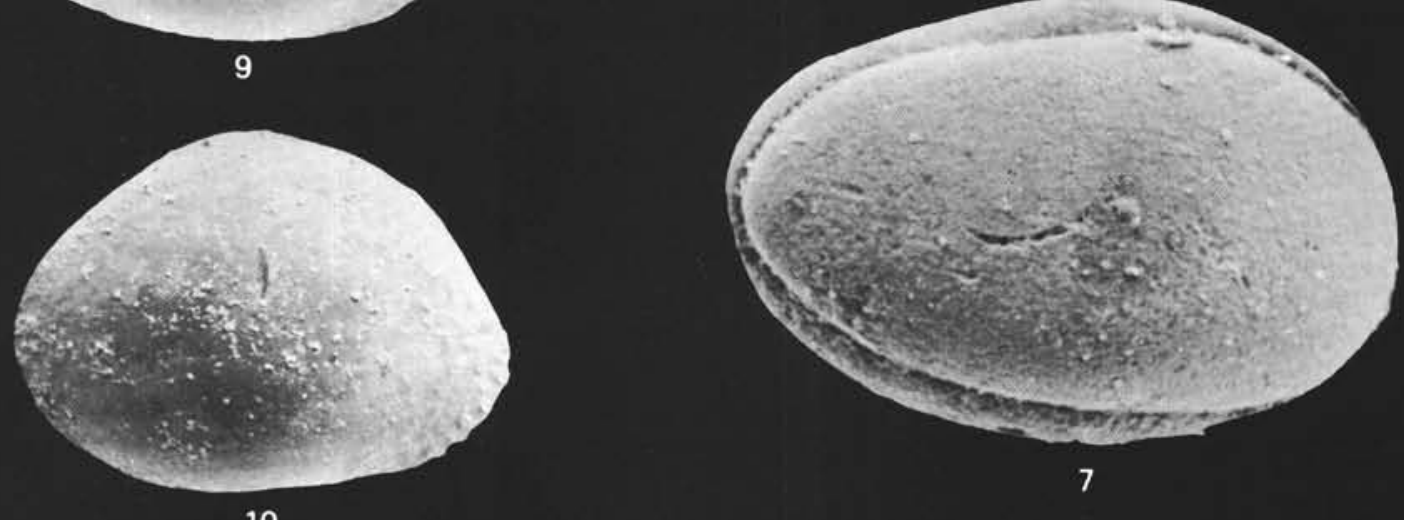


\section{PLATE 2}

Figures 1, $2 \quad$ Bairdia sp. 6 .

1. Left valve; Site 401, Sample 503, $119-121 \mathrm{~cm}$, middle Eocene, $\times 110$.

2. Carapace, dorsal view, Site 401, Sample 5-3, 119-121 cm, middle Eocene, $\times 110$.

Figure 3

Bairdia sp. 7.

Right valve; Site 404, Sample 6,CC, late Miocene, $\times 40$.

Figure 4

Bythocypris.

Right valve; Site 405, Sample 9,CC, middle eocene, $\times 50$.

Figure 5, 6 Cythere suhmi (Brady).

5. Left valve; Site 403, Sample 6,CC, late Pliocene, $\times 50$.

6. Right valve; Site 403, Sample 6,CC, late Pliocene, $\times 40$.

Figure 7

Agrenocythere sp. 1.

Left valve; Hole 400A, Sample 37-1,44-46 $\mathrm{cm}$, early Miocene, $\times 40$.

Figure $8 \quad$ Trachyleberidea prestwichiana (Jones and Sherborn).

Left valve; Site 405, Sample 9,CC, middle Eocene, $\times 60$.

Figure 9 Hazelina sp. 2.

Right valve; Site 405, Sample 10,CC, middle Eocene, $\times 110$.

Figure $10 \quad$ Hazelina?

Right valve; Site 403, Sample 43,CC, Paleocene, $\times 110$.

Figure $11 \quad$ Echinocythereis echinata (Sars).

Right valve; Site 405, Sample 3,CC, Quaternary, $\times 40$. 


\section{PLATE 2}
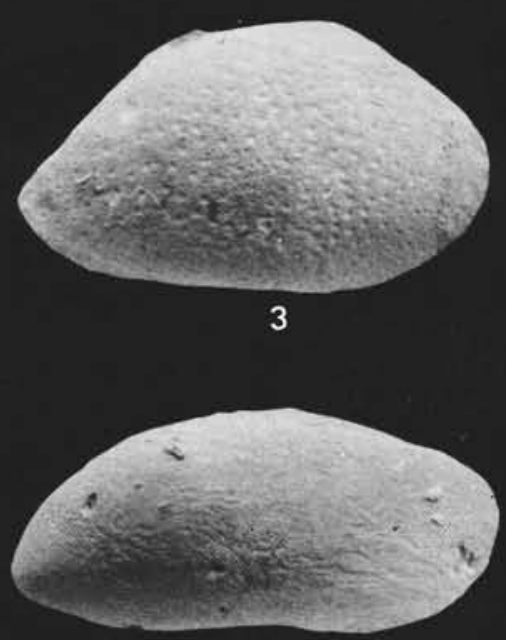

4

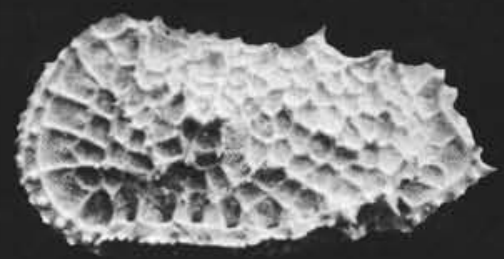

7

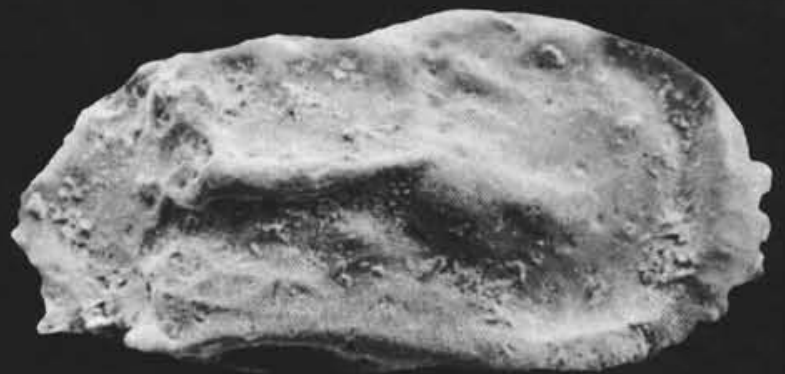

9

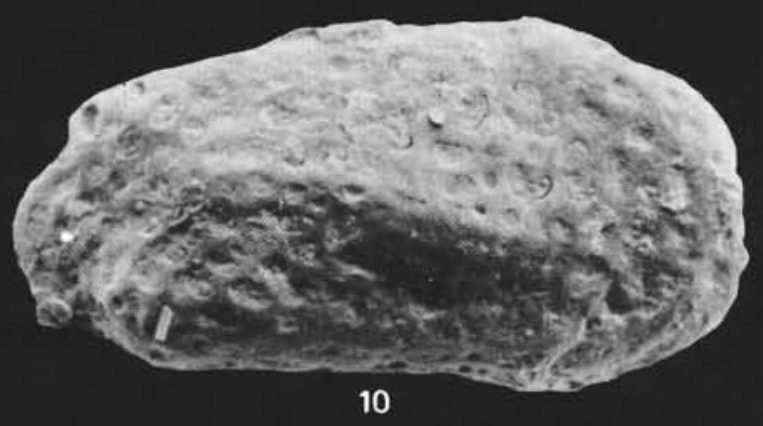

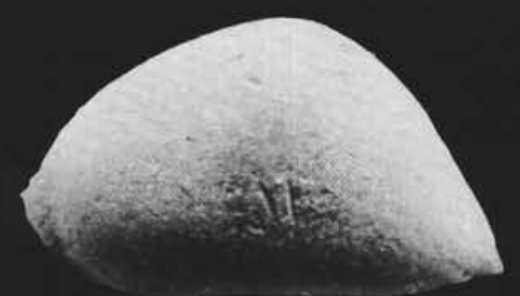

1

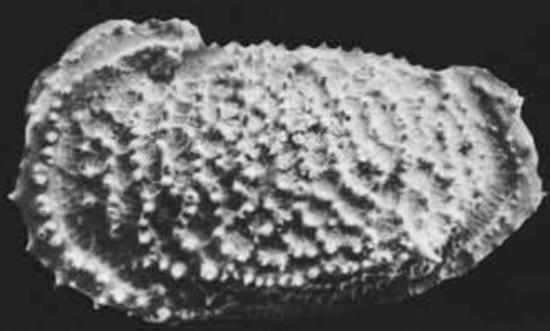

5

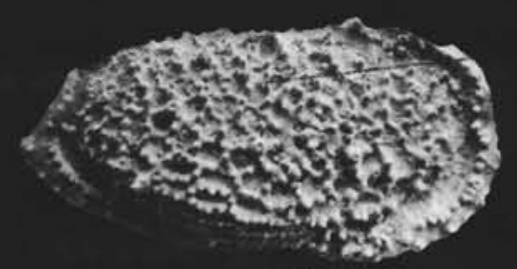

6

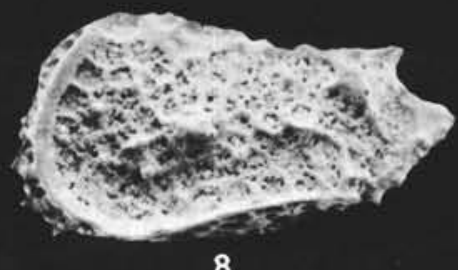

8

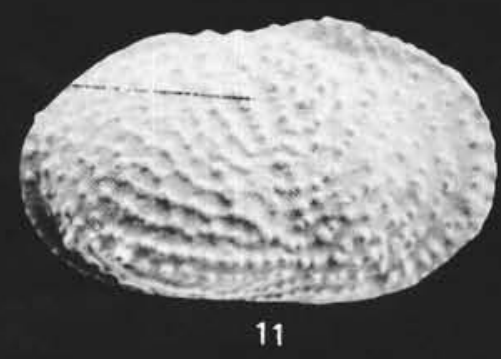




\section{PLATE 3}

Figure $1 \quad$ Henryhowella asperrima (Reuss).

Left valve; Site 403, Sample 7, CC, early Pliocene, $\times 60$.

Figure $2 \quad$ Atlanticythere sp. 1.

Left valve; Site 405, Sample 9, CC, middle Eocene, $\times 50$.

Figure 3 Oxycythereis dorsoserata.

Right valve; Site 405, Sample 4, CC, Quaternary, $\times 50$.

Figure $4 \quad$ Thalassocythere acanthoderma (Brady).

Right valve; Site 405, Sample 4, CC, Quaternary, $\times 40$.

Figure $5 \quad$ Buntonia sp. 3.

Left valve; Hole 400A, Sample 56-2, 60-63 cm, early Eocene, $\times 110$.

Figure $6 \quad$ Hermanites ? sp. 7 (smooth form),

Left valve; Site 405, Sample 4, CC, Quaternary, $\times 50$.

Figure 7 Hermanites ? sp. 8 (tuberculate form).

Carapace, right valve; Site 404, Sample 25, CC, Paleocene, $\times 50$.

Figure 8 Hermanites ? sp. 9 (reticulate form).

Right valve, Site 404, Sample 17, CC, early Eocene, $\times 110$.

Figure 9 Bradleya dictyon (Brady).

Left valve; Site 405, Sample 4, CC, Quaternary, $\times 50$. 


\section{PLATE 3}

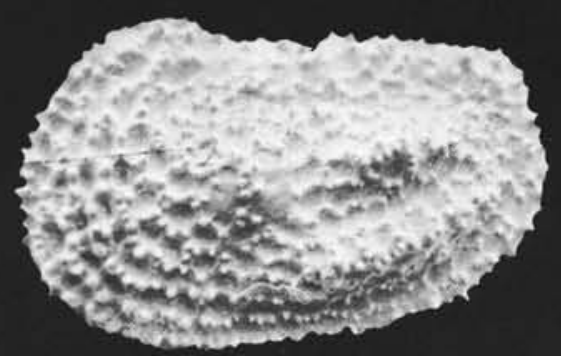

1
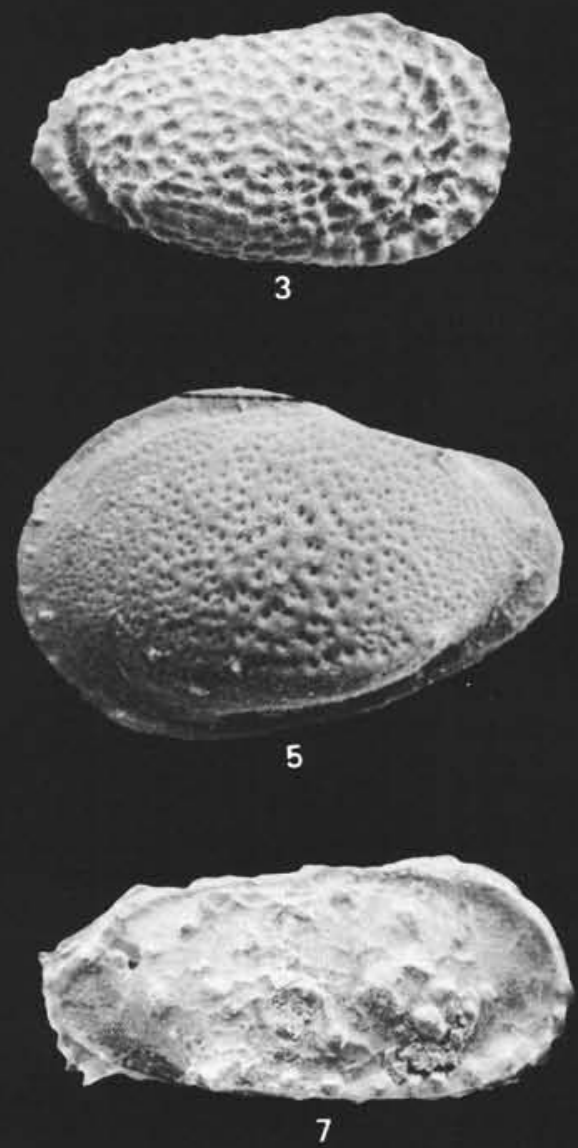
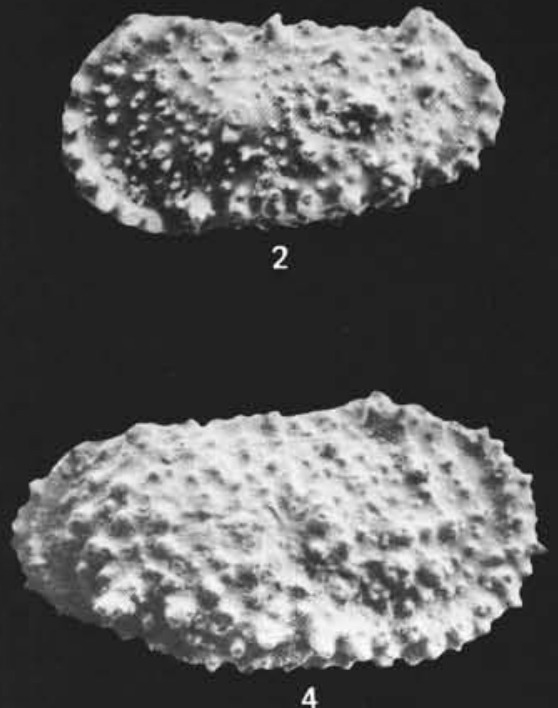

4
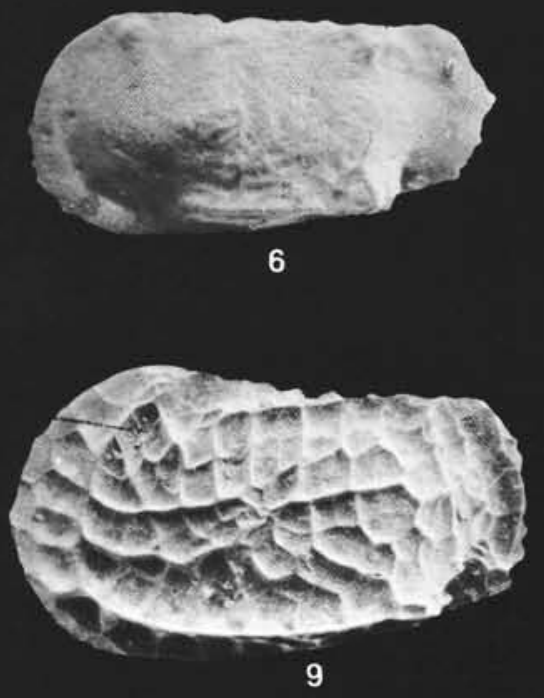

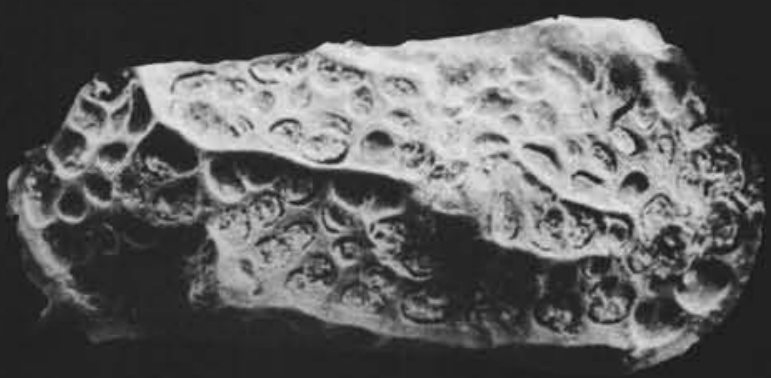

8 


\section{PLATE 4}

Figure 1

Figure 2

Figure 3

Figure 4

Figure 5

Figure 6

Figure 7

Figure 8
Poseidonamicus sp. 1.

Right valve; Site 404, Sample 5, CC, late Miocene, $\times 50$.

Bosquetina fenestratum (Brady).

Right valve; Site 405, Sample 7-1, Bottom, early Pliocene, $\times 110$.

Loxoconcha sp. 22.

Left valve; Site 404, Sample 17, CC, early Eocene, $\times 110$.

Eucytherura sp. 6.

Left valve; Site 401, Sample 10, CC, middle Eocene, $\times 280$.

Semicytherura sp. 8.

Right valve; Hole 400A, Sample 2-2, 114-116 cm, Quaternary, $\times 150$.

Juvenile form of Semicytherura sp. 9.

Right valve; Site 402, Sample 1, CC, Quaternary, $\times 110$.

Cytheropteron sp. 8.

Right valve, Hole 400A, Sample 1-1, 68-70 cm, Quaternary, $\times 150$.

Cytheropteron sp. 9.

Right valve; Site 402, Sample 5, CC, late Eocene, $\times 220$. 


\section{PLATE 4}

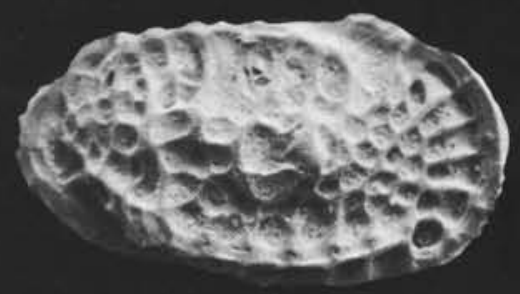

1

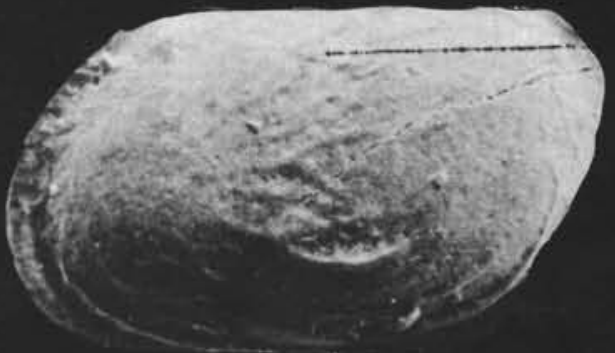

3

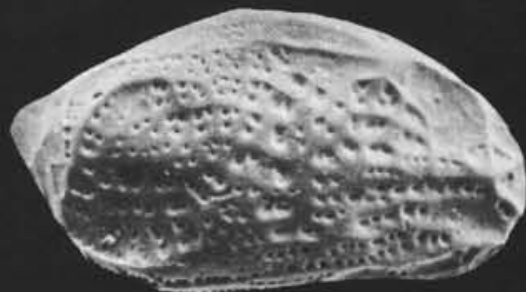

5
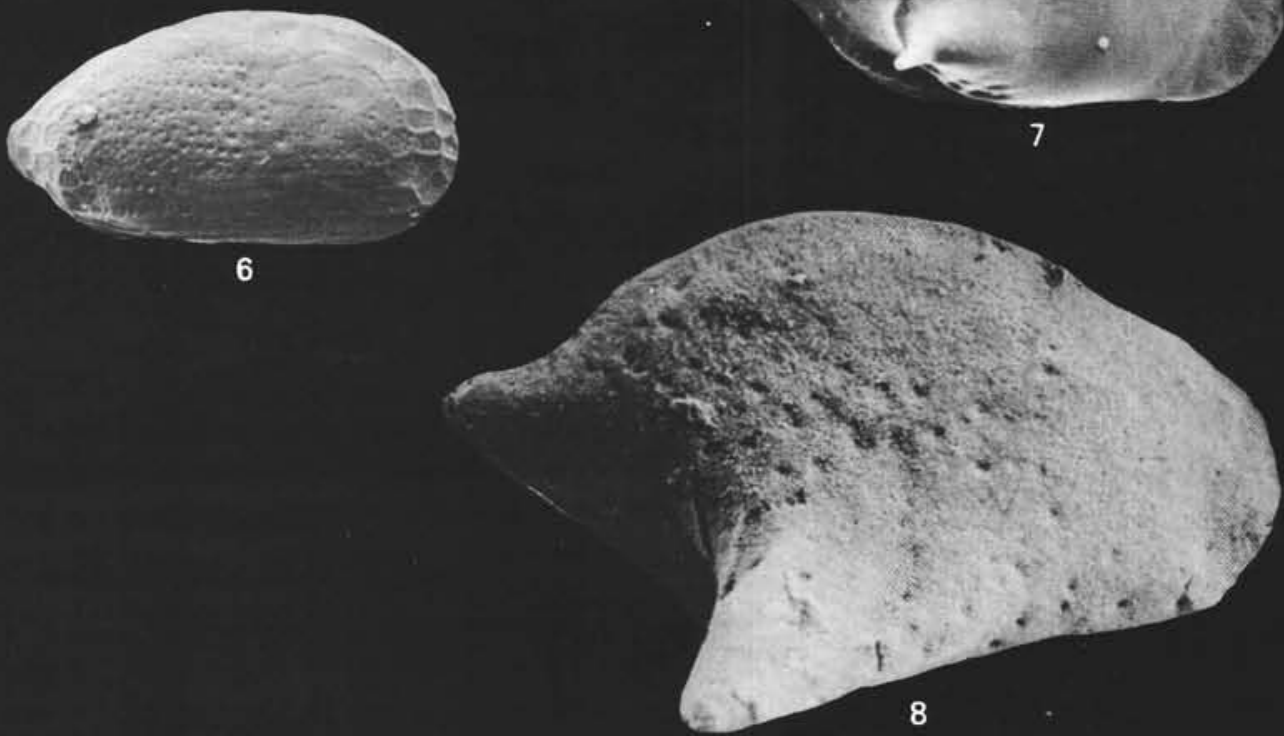


\section{PLATE 5}

Figures 1, 2 Cytheropteron sp. 10.

1. Right valve; Site 401, Sample 5-3, 119-121 cm, middle Eocene $\times 220$.

2. Left valve, dorsal view; Site 401, Sample 5-3, $119-121 \mathrm{~cm}$, middle Eocene, $\times 220$.

Figure $3 \quad$ Cytheropteron sp. 26.

Right valve; Site 403, Sample 15, CC, late Miocene, $\times 110$.

Figure $4 \quad$ Koilocythere sp. 1.

Left valve; Site 403, Sample 15, CC, late Miocene, $\times 110$.

Figure $5 \quad$ Xestoleberis sp. 2.

Right valve; Site 403, Sample 13, CC, late Miocene, $\times 110$.

Figure $6 \quad$ Argilloecia angulata (Deltel).

Carapace, left valve; Site 401, Sample 3, CC, late Eocene, $\times 110$.

Figure $7 \quad$ Argilloecia conoidea (Sars).

Left valve; Site 402, Sample 1, CC, Quaternary, $\times 150$.

Figure $8 \quad$ Paracypris sp. 6.

Right valve; Site 404, Sample 17, CC, early Eocene, $\times 50$.

Figure 9 Indet. gen. 3 .

Left valve; Site 406, Sample 1, CC, Quaternary, $\times 110$. 
PLATE 5

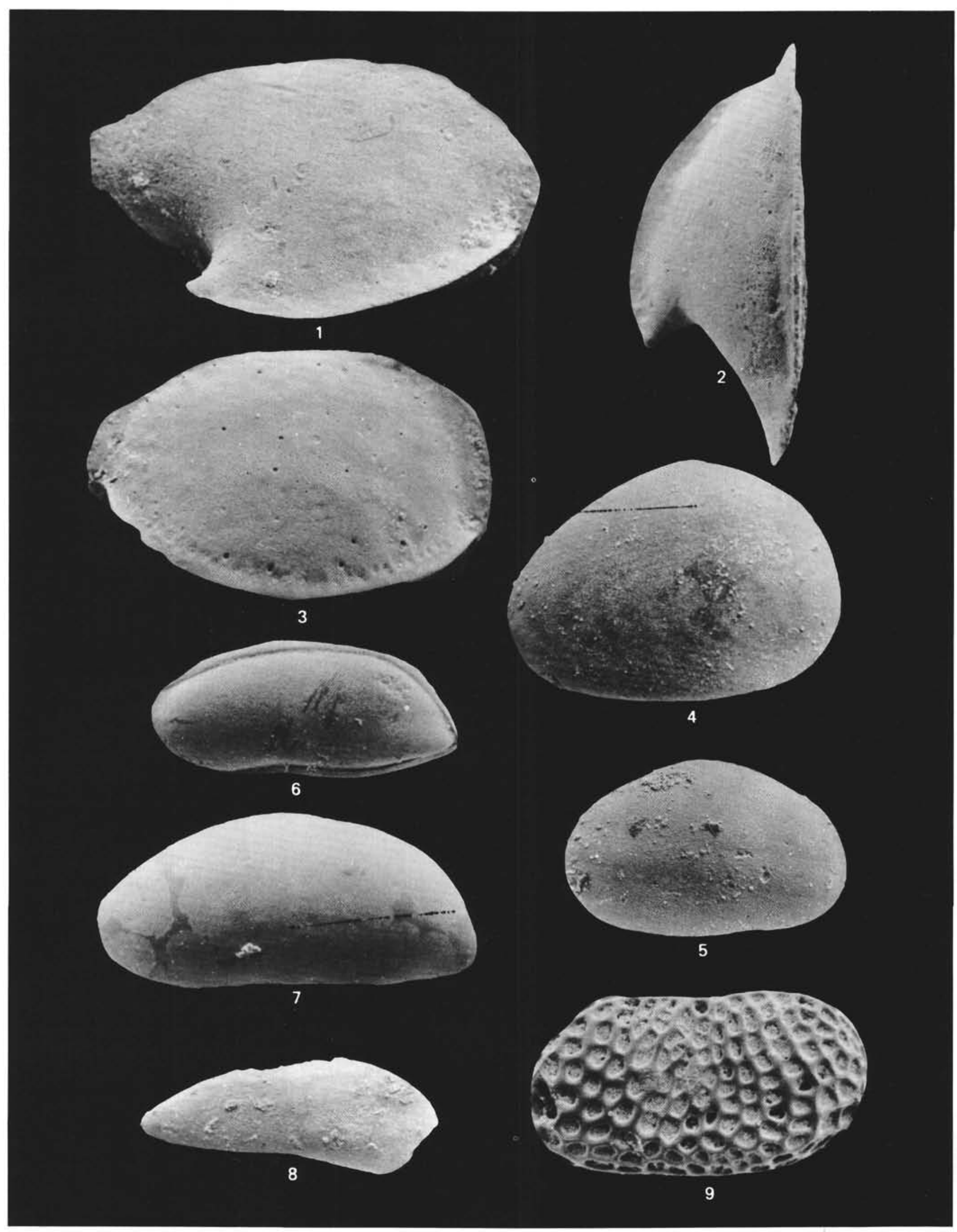

